\title{
Phytosociology and Behavior of Weeds in Maize as Influenced by Spatial Arrangements
}

\author{
Wanderson de Sousa Mendes ${ }^{1}$, Leandro Otávio Vieira Filho ${ }^{1}$, Nayana Alves Pereira ${ }^{1}$, Cácio Luiz Boechat ${ }^{2}$ \\ \& Fabio Mielezrski ${ }^{3}$ \\ ${ }^{1}$ Graduate Program of Soil and Plant Nutrition, "Luiz de Queiroz" College of Agriculture, University of São \\ Paulo, Piracicaba, São Paulo, Brazil \\ ${ }^{2}$ Campus Professora Cinobelina Elvas (CPCE), Federal University of Piauí, Bom Jesus, Piauí, Brazil \\ ${ }^{3}$ Department of Environmental and Plant Sciences, Federal University of Paraíba, Areia, Paraíba, Brazil \\ Correspondence: Wanderson de Sousa Mendes, Graduate Program of Soil and Plant Nutrition, "Luiz de Queiroz" \\ College of Agriculture, University of São Paulo, Ave. Padua Dias 11, CEP 13416-900, Piracicaba, São Paulo, \\ Brazil. Tel: 55-19-3417-2128. E-mail: wandersonsm@usp.br
}

Received: May 13, 2018

doi:10.5539/jas.v10n9p199
Accepted: June 22, $2018 \quad$ Online Published: August 15, 2018

URL: https://doi.org/10.5539/jas.v10n9p199

\begin{abstract}
Using the right spatial arrangement is a sustainable way to prevent or at least delay the emergence of weeds in the crop production. This study evaluated the influence of row spacing and plant density of maize on weed control based on the phytosociological survey. It was conducted on an Oxisol textured medium in a $400 \mathrm{~m}^{2}$ area under semiarid conditions. The hybrid maize $30 \mathrm{~F} 53 \mathrm{YH}$ was managed under a no-till cropping system with three types of row spacing $(0.35 \mathrm{~m}, 0.50 \mathrm{~m}$, and $0.70 \mathrm{~m})$ and three plant densities $\left(5.0\right.$ plants $\mathrm{m}^{-2}, 6.5$ plants $\mathrm{m}^{-2}$, and 8.0 plants $\mathrm{m}^{-2}$ ). The experimental design was randomized complete blocks with four replications in a factorial arrangement $3 \times 3$. The phytosociological survey of the weeds was randomly performed four times in each subplot, using the inventory square $(0.5 \mathrm{~m} \times 0.5 \mathrm{~m})$. The collected data were analyzed using the $\mathrm{R}$ statistical program. Among the specimen's families identified on the field, three of them need to be highlighted due to its high values of density, frequency, and dominance. These families were Fabaceae, Poaceae, and Amaranthaceae. Also, it was identified that the Leucaena leucocephala species may be classified as a weed, as it acted as an invasive species on maize. The weed control was greatly influenced by the interaction of both parameters rather than only row spacing or the plant density factor. The results showed that the reduced spacing and high crop population decreased the presence of weeds in the maize crop.
\end{abstract}

Keywords: crop management, herbs, weed biocontrol, Zea mays

\section{Introduction}

Maize (Zea mays L.) is an annual grass crop belonging to the Poaceae family and represents one of the most cultivated cereals, especially in tropical, subtropical and temperate regions. The total production of maize in Brazil in the year of 2015-2016 reached 48.2 million tons and the state of Piaui represented 3.65\% of that yield (CONAB, 2016). Increasing maize productivity depends directly on the technological level used in its cultivation, climate, fertilization and weed management (Barros, Faria, Tuffi Santos, Azevedo, \& Governici, 2017). These factors may compromise crop development.

Weeds are undesired species in cultivated crops (Ahmad, Khan, Abd Allah, Algarawi, \& Hashem, 2016). In the case of maize, for example, some weed species produce propagules that spread rapidly and compete with the main crop for space, water, light and nutrients (Barros et al., 2017; Mesquita, Andrade, \& Pereira, 2016). Studies have shown the resistance of weed species to chemicals used in several crops over time (Brunharo, Christoffoleti, \& Nicolai, 2014; Colbach, Darmency, Fernier, Granger, Le Corre, \& Messéan, 2017).

The phytosociological survey determines the floristic composition, distribution, structure, functioning and dynamics of the vegetation, therefore the basis for the studies of the plant communities (Pires, Prates, Pereira Filho, Oliveira Jr., \& Faria, 2001). Firstly, it is necessary to find out the ecological basis of weeds in a certain area and then the appropriate method that have to be chosen (Freitas \& Magalhães, 2012). A number of phytosociological parameters are mentioned in the literature, but Concenço, Thomazi, Correia, Santos, and 
Galon (2013) pointed out that density, frequency and dominance are the most significant parameters to describe the dynamics of weeds in agriculture. The most important species of herbs will be those with the highest number of individuals (density), wider distributed in the area (frequency), and those who are able to suppress the other species because of their growth and accumulation of faster mass (dominance).

In this context, it is fundamental to develop studies targeting the control mechanisms that are efficient in reducing weeds, since the research conducted for phytosociological studies in Brazil is still considered insufficient (Freitas \& Magalhães, 2012). Therefore, the handling of the spatial arrangement of the crop of interest is fundamental in the control of weeds and constitutes a socially, economically and environmentally sustainable alternative. The present study had the objective of evaluating the influence of population spacing and density of maize plants on weed control based on the phytosociological survey.

\section{Materials and Methods}

\subsection{Study Area and Experimental Design}

This study was conducted on an Oxisol textured medium (Soil Survey Staff, 2014) in a $400 \mathrm{~m}^{2}$ area under semiarid condition at the Federal University of Piauí located in Bom Jesus city, Piauí State, Brazil (09 04'47" S; $44^{\circ} 19^{\prime} 37.60^{\prime \prime} \mathrm{W} ; 285 \mathrm{~m}$ asl.). According to Köppen's climate classification (Alvares, Stape, Sentelhas, de Moraes Gonçalves, \& Sparovek, 2013), the region is a Tropical zone with dry winter (Aw) and the average annual rainfall is about $880 \mathrm{~mm}$. The maize hybrid $30 \mathrm{~F} 53 \mathrm{YH}$ was managed under a no-till cropping system from January 8, 2016 to April 17, 2016. The experimental design consisted of three types of row spacing $(0.35 \mathrm{~m}, 0.50$ $\mathrm{m}$, and $0.70 \mathrm{~m})$ and three plant densities $\left(5.0\right.$ plants $\mathrm{m}^{-2}, 6.5$ plants $\mathrm{m}^{-2}$, and 8.0 plants $\left.\mathrm{m}^{-2}\right)$ in a factorial arrangement $3 \times 3$. Row spacing was the plot and plant densities were the subplot. This is a randomized complete block design and each subplot consisted of 4 rows with $3 \mathrm{~m}$ length. By vegetative stage (V2), the maize plants were thinned out to preserve the aimed plant density. Fertilization was performed according to soil analysis (Table 1), as well as the topdressing fertilizer in the initial phase of maize cultivation.

Table 1. Soil chemical analysis of the study area

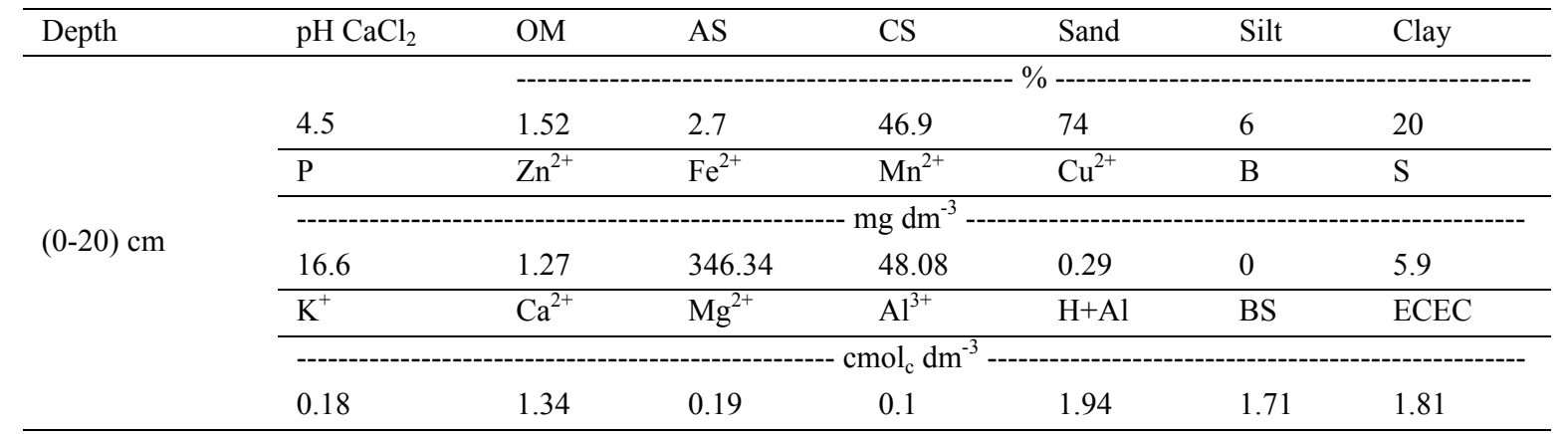

Note. $\mathrm{OM}=$ organic matter; $\mathrm{AS}=$ aluminium saturation; $\mathrm{CS}=$ cation saturation; $\mathrm{BS}=$ base saturation; $\mathrm{ECEC}=$ effective cation exchange capacity.

\subsection{Field Collection}

At the vegetative stage (V6), the phytosociological survey of the weeds was randomly performed in each subplot, four times, using the inventory square $(0.5 \mathrm{~m} \times 0.5 \mathrm{~m})$ standard method, as explained by Braun-Blanquet (1979) and Erasmo, Pinheiro, \& Costa (2004). Then, the species existent in the central point were counted and identified in field and laboratory, based on the Brazilian weed identification guide (Lorenzi, 2006). Additionally, the samples were air dried in the oven at $65^{\circ} \mathrm{C}$ and weighed in their total amount. The $\mathrm{V} 6$ vegetative stage of maize growth stage was chosen because of weed competition.

\subsection{Statistical Analysis}

Data were analysed using the R-package ExpDes (Ferreira, Cavalganti, \& Nogueira, 2014) for better visualisation of the results. Moreover, the phytosociological parameters were expressed using the Mueller-Dombois and Ellenberg (1974) equations:

$$
\mathrm{Af}_{\mathrm{j}}=\frac{\mathrm{Np}_{\mathrm{j}}}{\mathrm{n}}
$$




$$
\begin{aligned}
\mathrm{Rf}_{\mathrm{j}}= & \left(\frac{\mathrm{Af}_{\mathrm{j}}}{\sum_{\mathrm{k}=1}^{\mathrm{p}} \mathrm{Af}_{\mathrm{k}}}\right) \times 100 \% \\
& \mathrm{Ad}_{\mathrm{j}}=\frac{\mathrm{Nj}}{\mathrm{A}} \\
\mathrm{Dr}_{\mathrm{j}}= & \left(\frac{\mathrm{Da}_{\mathrm{j}}}{\sum_{\mathrm{k}=1}^{\mathrm{p}} \mathrm{Da}_{\mathrm{k}}}\right) \times 100 \% \\
& \mathrm{Aa_{j }}=\frac{\mathrm{Np}_{\mathrm{j}}}{\mathrm{TNp}_{\mathrm{j}}} \\
\mathrm{Ra}_{\mathrm{j}}= & \left(\frac{\mathrm{Aa}_{\mathrm{j}}}{\sum_{\mathrm{k}=1}^{\mathrm{p}} \mathrm{Aa}_{\mathrm{k}}}\right) \times 100 \% \\
\mathrm{IVI}_{\mathrm{j}}= & \mathrm{Rf}_{\mathrm{j}}+\mathrm{Rd}_{\mathrm{j}}+\mathrm{Ra}_{\mathrm{j}}
\end{aligned}
$$

where, $\mathrm{Af}_{\mathrm{j}}$ is the absolute frequency of the species $\mathrm{j}, \mathrm{Np}_{\mathrm{j}}$ is the number of points where the species $\mathrm{j}$ occurs, $\mathrm{n}$ is the total number of points, $\mathrm{Rf}_{\mathrm{j}}$ is the relative frequency of the species $\mathrm{j}, \sum_{\mathrm{k}=1}^{\mathrm{p}} \mathrm{Af} \mathrm{f}_{\mathrm{k}}$ is the sum of the absolute frequencies for all species (i.e. $\mathrm{k}$ is the species number, and $\mathrm{p}$ is the total number of species), $\mathrm{Ad}_{\mathrm{j}}$ is the absolute density of species $\mathrm{j}, \mathrm{Nj}$ is the total number of occurrences of species $\mathrm{j}, \mathrm{A}$ is the total area sampled, $R \mathrm{~d}_{\mathrm{j}}$ is the relative density of species $\mathrm{j}, \sum_{\mathrm{k}=1}^{\mathrm{p}} \mathrm{Ad}_{\mathrm{k}}$ is the sum of the absolute densities for all species, $\mathrm{Aa}_{\mathrm{j}}$ is the absolute abundance of species $\mathrm{j}, \mathrm{TNp}_{\mathrm{j}}$ is the total number of points where the species $\mathrm{j}$ occurs, $\sum_{\mathrm{k}=1}^{\mathrm{p}} \mathrm{Aa}_{\mathrm{k}}$ is the sum of the absolute abundances for all species, $R a_{j}$ is the relative abundance of species $j$, and $\mathrm{IVI}_{\mathrm{j}}$ is the importance value index of the species $j$.

It was used the R program (R Development Core Team, 2017) to perform statistical tests Tukey $(\mathrm{p}<0.05)$ and Shapiro-Wilk, analysis of variance (ANOVA), unfolding the interactions (population density and spacing). Furthermore, all data were analyzed by performing and free prediction of the effect of blocks through both $\mathrm{R}$ packages ExpDes and Agricolae. Additionally, the data were normalized by Box-Cox transformation to obtain homogenous variances.

\section{Results}

\subsection{Phytosociological Survey}

In terms of weed distribution and frequency, the order Caryophyllales was represented by four species within two families. Only one family was observed in Cyperales and Fabales orders wherein there were four species

\begin{tabular}{|c|c|c|}
\hline Scientific name & Order & Family \\
\hline $\begin{array}{l}\text { Portulaca oleracea } L \text {. } \\
\text { Amaranthus defle:us }\end{array}$ & Caryophyllales & Portulacaceae \\
\hline $\begin{array}{l}\text { Alternanthera tenella Colla } \\
\text { Amaranthus viridis }\end{array}$ & & Amaranthaceae \\
\hline $\begin{array}{l}\text { Commelina benghalensis } L \text {. } \\
\text { Sidastrum micranthum }\end{array}$ & Commelinales & Commelinaceae \\
\hline Eleusine indica (L.) Gaertn. & & \\
\hline $\begin{array}{c}\text { Echinochloa crus-pavonis } \\
\text { Digitaria insularis } \\
\text { Clhoris spp. }\end{array}$ & Cyperales & Poaceae \\
\hline Leucaena leucocephala & & \\
\hline $\begin{array}{l}\text { Aeschynomene rudis } \\
\text { Senna obtusifolia } \\
\text { Senna occidentaiis }\end{array}$ & Fabales & $\begin{array}{l}\text { Fabaceae / } \\
\text { Leguminosae }\end{array}$ \\
\hline Leonotis nepetifolia & Lamiales & Lamiaceae Labiatae \\
\hline Sida santaremnensis H. Monteiro & Malvales & Malvaceae \\
\hline Spermacoce latifolia & Rubiales & Rubiaceae \\
\hline
\end{tabular}
each. Two specimens of Commelinales were organized in the collections from a unique family. One specimen of Lamiales was identified by one species. The same occurred to the orders Malvales and Rubiales (Figure 1a). The three most distinguishable families were Fabaceae, Poaceae, and Amaranthaceae (Figure 1b). Therefore, seventeen specimens, representing seven orders and eight families were organized in the collection at the study area.

(a)

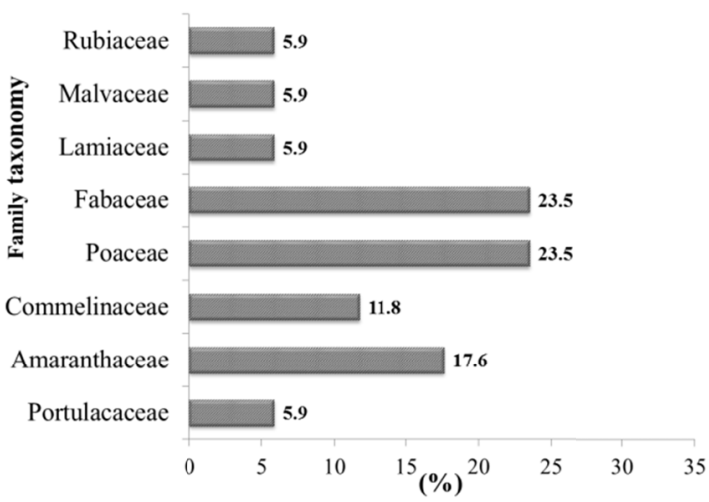

(b)

Figure 1. Scientific names, order and family hierarchy of weeds under different maize spatial arrangement (a) and specimen's percent distribution by family (b)

Analyzing the row spacing of $0.35 \mathrm{~m}$ (Table 2), we can identify that the species Eleusine indica (L.) Gaertn (IVI $=63.39 \%)$, Portulaca oleracea $\mathrm{L} .(\mathrm{IVI}=55.28 \%)$, Alternanthera tenella Colla $(\mathrm{IVI}=52.11 \%)$ and Leucaena leucocephala $(\mathrm{IVI}=47.16 \%)$ have more representative than other species in that sequence within 5.0 plants $\mathrm{m}^{-2}$. 
By 6.5 plants $\mathrm{m}^{-2}$, Leucaena leucocephala (IVI $\left.=85.14 \%\right)$, Eleusine indica (L.) Gaertn (IVI $=66.27 \%$ ), Alternanthera tenella Colla (IVI $=42.22 \%$ ) and Portulaca oleracea L. (IVI $=36.21 \%$ ) showed high relative abundance, frequency and density. In the plant density of 8.0 plants $\mathrm{m}^{-2}$, Eleusine indica (L.) Gaertn and Leucaena leucocephala had the same degree of importance (IVI $=58.65 \%$ ) comparing to other species. Overall, these two species displayed high-ranking phytosociological index.

Table 2. Phytosociological values of the weed species in maize under the row spacing of $0.35 \mathrm{~m}$

\begin{tabular}{|c|c|c|c|c|c|c|c|c|c|c|c|c|}
\hline \multirow{3}{*}{ Scientific name } & \multicolumn{12}{|c|}{ Row spacing of $0.35 \mathrm{~m}$} \\
\hline & \multicolumn{4}{|c|}{5.0 plants $\mathrm{m}^{-2}$} & \multicolumn{4}{|c|}{6.5 plants $\mathrm{m}^{-2}$} & \multicolumn{4}{|c|}{8.0 plants $\mathrm{m}^{-2}$} \\
\hline & $\operatorname{Rf}(\%)$ & $\mathrm{Rd}(\%)$ & $\mathrm{Ra}(\%)$ & IVI & $\operatorname{Rf}(\%)$ & $\operatorname{Rd}(\%)$ & $\mathrm{Ra}(\%)$ & IVI & $\operatorname{Rf}(\%)$ & $\operatorname{Rd}(\%)$ & $\mathrm{Ra}(\%)$ & IVI \\
\hline Eleusine indica (L.) Gaertn. & 18.75 & 25.00 & 19.64 & 63.39 & 18.18 & 28.57 & 19.51 & 66.27 & 12.50 & 23.08 & 23.08 & 58.65 \\
\hline Portulaca oleracea L. & 18.75 & 20.45 & 16.07 & 55.28 & 18.18 & 10.71 & 7.32 & 36.21 & 12.50 & 7.69 & 7.69 & 27.88 \\
\hline Amaranthus deflexus & 12.50 & 9.09 & 10.71 & 32.31 & 9.09 & 3.57 & 4.88 & 17.54 & 12.50 & 7.69 & 7.69 & 27.88 \\
\hline Alternanthera tenella Colla & 12.50 & 18.18 & 21.43 & 52.11 & 18.18 & 14.29 & 9.76 & 42.22 & 6.25 & 11.54 & 23.08 & 40.87 \\
\hline Spermacoce latifolia & 12.50 & 6.82 & 8.04 & 27.35 & 9.09 & 3.57 & 4.88 & 17.54 & 6.25 & 3.85 & 7.69 & 17.79 \\
\hline Leucaena leucocephala & 12.50 & 15.91 & 18.75 & 47.16 & 9.09 & 32.14 & 43.90 & 85.14 & 12.50 & 23.08 & 23.08 & 58.65 \\
\hline Echinochloa crus-pavonis & 0.00 & 0.00 & 0.00 & 0.00 & 9.09 & 3.57 & 4.88 & 17.54 & 0.00 & 0.00 & 0.00 & 0.00 \\
\hline Aeschynomene rudis & 6.25 & 2.27 & 0.00 & 8.52 & 0.00 & 0.00 & 0.00 & 0.00 & 12.50 & 7.69 & 0.00 & 20.19 \\
\hline Leonotis nepetifolia & 6.25 & 2.27 & 5.36 & 13.88 & 9.09 & 3.57 & 4.88 & 17.54 & 12.50 & 7.69 & 7.69 & 27.88 \\
\hline Amaranthus viridis & 0.00 & 0.00 & 0.00 & 0.00 & 0.00 & 0.00 & 0.00 & 0.00 & 6.25 & 3.85 & 0.00 & 10.10 \\
\hline Chloris spp. & 0.00 & 0.00 & 0.00 & 0.00 & 0.00 & 0.00 & 0.00 & 0.00 & 6.25 & 3.85 & 0.00 & 10.10 \\
\hline Total & 100 & 100 & 100 & 300 & 100 & 100 & 100 & 300 & 100 & 100 & 100 & 300 \\
\hline
\end{tabular}

Note. $\mathrm{Rf}=$ Relative Frequency; $\mathrm{Rd}=$ Relative Density; $\mathrm{Ra}=$ Relative Abundance; IVI = Importance Value Index (IVI).

Fifteen specimens were taken in treatment $0.50 \mathrm{~m}$ (Table 3). The specimens of P. oleracea L., A. deflexus and $L$. leucocephala were more abundant than others in the treatment of 5.0 plants $\mathrm{m}^{-2}$. Their IVI were around $50 \%$. At 6.5 plants $\mathrm{m}^{-2}, A$. deflexus and L. leucocephala kept high-ranking showing IVI over $60 \%$. Eleusine indica (L.) Gaertn. (IVI $=105.71 \%)$ and $A$. deflexus $(\mathrm{IVI}=47.64 \%$ ) were the most important specimens under 8.0 plants $\mathrm{m}^{-2}$.

Table 3. Phytosociological values of the weed species in maize under the row spacing of $0.50 \mathrm{~m}$

\begin{tabular}{|c|c|c|c|c|c|c|c|c|c|c|c|c|}
\hline \multirow{3}{*}{ Scientific name } & \multicolumn{12}{|c|}{ Row spacing of $0.50 \mathrm{~m}$} \\
\hline & \multicolumn{4}{|c|}{5.0 plants $\mathrm{m}^{-2}$} & \multicolumn{4}{|c|}{6.5 plants $\mathrm{m}^{-2}$} & \multicolumn{4}{|c|}{8.0 plants $\mathrm{m}^{-2}$} \\
\hline & $\operatorname{Rf}(\%)$ & $\operatorname{Rd}(\%)$ & $\mathrm{Ra}(\%)$ & IVI & $\mathrm{Rf}(\%)$ & $\operatorname{Rd}(\%)$ & $\mathrm{Ra}(\%)$ & IVI & $\operatorname{Rf}(\%)$ & $\operatorname{Rd}(\%)$ & $\operatorname{Ra}(\%)$ & IVI \\
\hline Eleusine indica (L.) Gaertn. & 6.25 & 7.41 & 22.22 & 35.88 & 12.50 & 10.64 & 16.13 & 39.27 & 15.38 & 45.16 & 45.16 & 105.71 \\
\hline Portulaca oleracea L. & 12.50 & 14.81 & 22.22 & 49.54 & 6.25 & 2.13 & 6.45 & 14.83 & 7.69 & 3.23 & 6.45 & 17.37 \\
\hline Amaranthus deflexus & 12.50 & 14.81 & 22.22 & 49.54 & 18.75 & 42.55 & 43.01 & 104.31 & 15.38 & 16.13 & 16.13 & 47.64 \\
\hline Alternanthera tenella Colla & 12.50 & 7.41 & 11.11 & 31.02 & 6.25 & 2.13 & 6.45 & 14.83 & 7.69 & 6.45 & 12.90 & 27.05 \\
\hline Spermacoce latifolia & 0.00 & 0.00 & 0.00 & 0.00 & 0.00 & 0.00 & 0.00 & 0.00 & 7.69 & 3.23 & 6.45 & 17.37 \\
\hline Leucaena leucocephala & 12.50 & 14.81 & 22.22 & 49.54 & 18.75 & 21.28 & 21.51 & 61.53 & 7.69 & 3.23 & 6.45 & 17.37 \\
\hline Echinochloa crus-pavonis & 6.25 & 11.11 & 0.00 & 17.36 & 6.25 & 2.13 & 6.45 & 14.83 & 7.69 & 3.23 & 0.00 & 10.92 \\
\hline Aeschynomene rudis & 0.00 & 0.00 & 0.00 & 0.00 & 6.25 & 2.13 & 0.00 & 8.38 & 7.69 & 3.23 & 0.00 & 10.92 \\
\hline Leonotis nepetifolia & 0.00 & 0.00 & 0.00 & 0.00 & 0.00 & 0.00 & 0.00 & 0.00 & 7.69 & 3.23 & 6.45 & 17.37 \\
\hline Senna obtusifolia & 6.25 & 3.70 & 0.00 & 9.95 & 0.00 & 0.00 & 0.00 & 0.00 & 0.00 & 0.00 & 0.00 & 0.00 \\
\hline Senna occidentalis & 0.00 & 0.00 & 0.00 & 0.00 & 12.50 & 12.77 & 0.00 & 25.27 & 7.69 & 6.45 & 0.00 & 14.14 \\
\hline Sida santaremnensis H. Monteiro & 6.25 & 3.70 & 0.00 & 9.95 & 0.00 & 0.00 & 0.00 & 0.00 & 0.00 & 0.00 & 0.00 & 0.00 \\
\hline Digitaria insularis & 18.75 & 14.81 & 0.00 & 33.56 & 6.25 & 2.13 & 0.00 & 8.38 & 7.69 & 6.45 & 0.00 & 14.14 \\
\hline Commelina benghalensis L. & 0.00 & 0.00 & 0.00 & 0.00 & 6.25 & 2.13 & 0.00 & 8.38 & 0.00 & 0.00 & 0.00 & 0.00 \\
\hline Chloris spp. & 6.25 & 7.41 & 0.00 & 13.66 & 0.00 & 0.00 & 0.00 & 0.00 & 0.00 & 0.00 & 0.00 & 0.00 \\
\hline Total & 100.00 & 100.00 & 100.00 & 300.00 & 100.00 & 100.00 & 100.00 & 300.00 & 100.00 & 100.00 & 100.00 & 300.00 \\
\hline
\end{tabular}

Note $. \mathrm{Rf}=$ Relative Frequency; $\mathrm{Rd}=$ Relative Density; $\mathrm{Ra}=$ Relative Abundance; IVI = Importance Value Index (IVI). 
The specimens identified in row spacing of $0.70 \mathrm{~m}$ are summarized in Table 4. The foremost point is that $A$. tenella Colla showed higher importance value index into the three-plant density compared with others. The second relevant species was $E$. indica in the plant densities of 5.0 plants $\mathrm{m}^{-2}$ and 6.5 plants $\mathrm{m}^{-2}$. It was only above L. leucocephala in the plant density of 8.0 plants $\mathrm{m}^{-2}$. Thus, the total number of specimens for this treatment was ten.

Table 4. Phytosociological values of the weed species in maize under the row spacing of $0.70 \mathrm{~m}$

\begin{tabular}{|c|c|c|c|c|c|c|c|c|c|c|c|c|}
\hline \multirow{3}{*}{ Scientific name } & \multicolumn{12}{|c|}{ Row spacing of $0.70 \mathrm{~m}$} \\
\hline & \multicolumn{4}{|c|}{5.0 plants $\mathrm{m}^{-2}$} & \multicolumn{4}{|c|}{6.5 plants $\mathrm{m}^{-2}$} & \multicolumn{4}{|c|}{8.0 plants $\mathrm{m}^{-2}$} \\
\hline & $\operatorname{Rf}(\%)$ & $\operatorname{Rd}(\%)$ & $\operatorname{Ra}(\%)$ & IVI & $\operatorname{Rf}(\%)$ & $\operatorname{Rd}(\%)$ & $\mathrm{Ra}(\%)$ & IVI & $\operatorname{Rf}(\%)$ & $\operatorname{Rd}(\%)$ & $\operatorname{Ra}(\%)$ & IVI \\
\hline Eleusine indica (L.) Gaertn. & 18.75 & 15.38 & 8.51 & 42.65 & 25.00 & 23.33 & 13.08 & 61.42 & 10.00 & 13.64 & 16.22 & 39.85 \\
\hline Portulaca oleracea L. & 6.25 & 2.56 & 4.26 & 13.07 & 16.67 & 10.00 & 8.41 & 35.08 & 20.00 & 4.55 & 2.70 & 27.25 \\
\hline Amaranthus deflexus & 12.50 & 7.69 & 6.38 & 26.58 & 8.33 & 3.33 & 5.61 & 17.27 & 10.00 & 2.27 & 2.70 & 14.98 \\
\hline Alternanthera tenella Colla & 6.25 & 35.90 & 59.57 & 101.72 & 8.33 & 23.33 & 39.25 & 70.92 & 10.00 & 54.55 & 64.86 & 129.41 \\
\hline Spermacoce latifolia & 12.50 & 7.69 & 6.38 & 26.58 & 8.33 & 3.33 & 5.61 & 17.27 & 10.00 & 2.27 & 2.70 & 14.98 \\
\hline Leucaena leucocephala & 12.50 & 12.82 & 10.64 & 35.96 & 16.67 & 20.00 & 16.82 & 53.49 & 20.00 & 18.18 & 10.81 & 48.99 \\
\hline Leonotis nepetifolia & 6.25 & 2.56 & 4.26 & 13.07 & 8.33 & 6.67 & 11.21 & 26.21 & 0.00 & 0.00 & 0.00 & 0.00 \\
\hline Senna occidentalis & 12.50 & 7.69 & 0.00 & 20.19 & 0.00 & 0.00 & 0.00 & 0.00 & 10.00 & 2.27 & 0.00 & 12.27 \\
\hline Digitaria insularis & 6.25 & 5.13 & 0.00 & 11.38 & 8.33 & 10.00 & 0.00 & 18.33 & 10.00 & 2.27 & 0.00 & 12.27 \\
\hline Sidastrum micranthum & 6.25 & 2.56 & 0.00 & 8.81 & 0.00 & 0.00 & 0.00 & 0.00 & 0.00 & 0.00 & 0.00 & 0.00 \\
\hline Total & 100.00 & 100.00 & 100.00 & 300.00 & 100.00 & 100.00 & 100.00 & 300.00 & 100.00 & 100.00 & 100.00 & 300.00 \\
\hline
\end{tabular}

Note. $\mathrm{Rf}=$ Relative Frequency; $\mathrm{Rd}=$ Relative Density; $\mathrm{Ra}=$ Relative Abundance; IVI = Importance Value Index (IVI).

It can be identified that four species (E. indica, L. leucocephala, A. tenella, and P. oleracea) had high number of individuals in $0.35 \mathrm{~m}$ row spacing (Figure $2 \mathrm{a}$ ). This result does not significantly differ from $0.50 \mathrm{~m}$ (Figure $2 \mathrm{~b}$ ) and $0.70 \mathrm{~m}$ (Figure 2c) row spacing, wherein three species were highlighted in each treatment. A. deflexus, E. indica and L. leucocephala were the species of the first one and A. tenella, E. indica and L. leucocephala of the last one. The most striking result to emerge from the data is that E. indica, and L. leucocephala had higher number of observations in the treatments. 
(a)

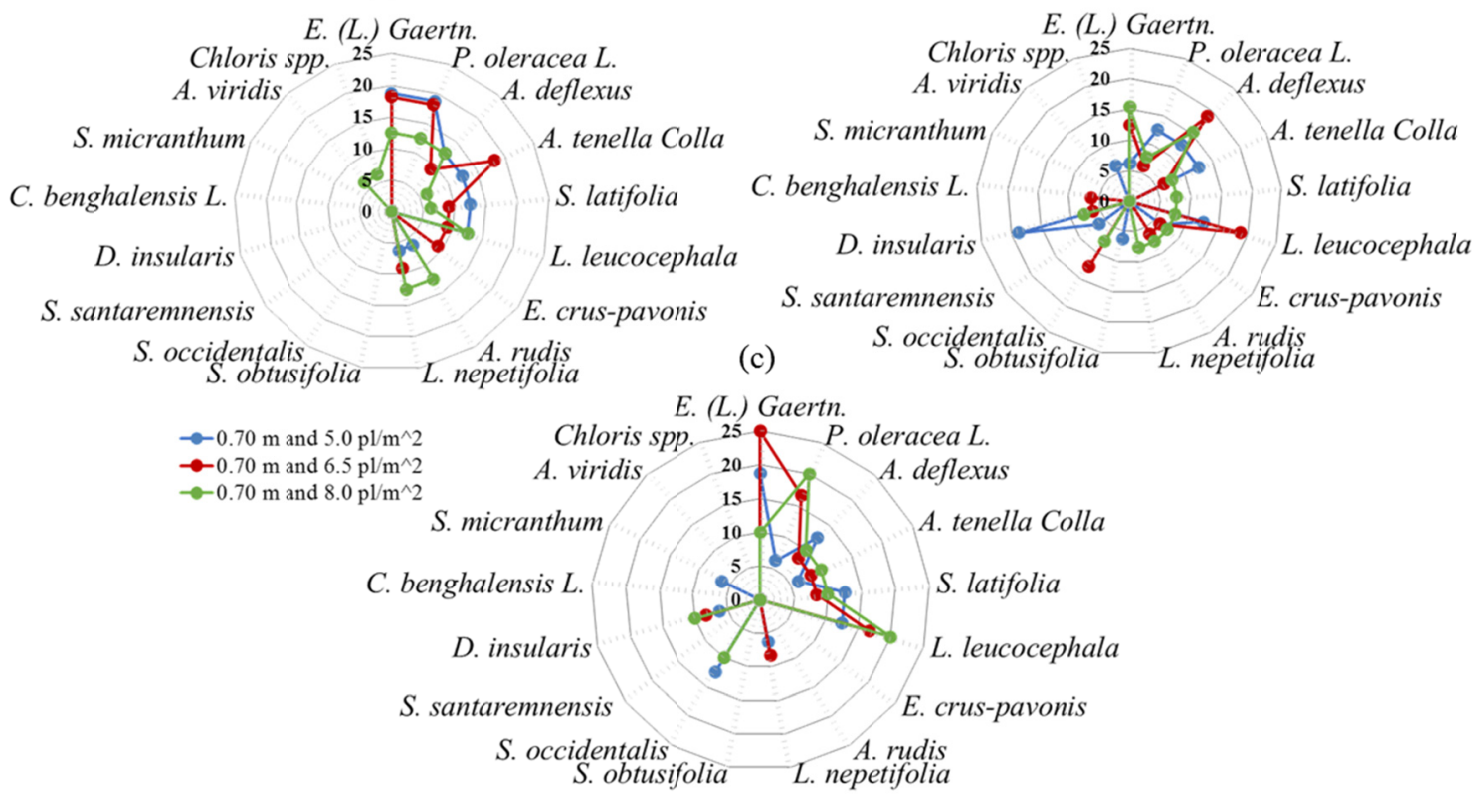

Figure 2. The number of specimen's observations in the $0.35 \mathrm{~m}(\mathrm{a}), 0.50 \mathrm{~m}(\mathrm{~b})$, and $0.70 \mathrm{~m}$ (c) row spacing into three plant densities

The dry matter related to the total number of individuals of each specimen was also measured (Table 5). Closer inspection of the table shows $E$. indica at the top had a dry matter content of $254 \mathrm{~g}$. This confirms their presence in all treatments as mentioned in the previous results.

Table 5. Specimen`s dry matter and the total number of individuals in all treatments

\begin{tabular}{lc}
\hline Species & Dry matter $(\mathrm{g})$ \\
\hline Eleusine indica (L.) Gaertn. & 254.00 \\
Alternanthera tenella Colla & 50.00 \\
Amaranthus deflexus & 26.00 \\
Leucaena leucocephala & 26.00 \\
Portulaca oleracea L. & 24.00 \\
Senna occidentalis & 10.00 \\
Digitaria insularis & 8.00 \\
Clhoris spp. & 6.00 \\
Spermacoce latifolia & 3.00 \\
Leonotis nepetifolia & 1.38 \\
Commelina benghalensis L. & 1.38 \\
Senna obtusifolia & 0.71 \\
Echinochloa crus-pavonis & 0.60 \\
Aeschynomene rudis & 0.36 \\
Sidastrum micranthum & 0.23 \\
Sida santaremnensis H. Monteiro & 0.13 \\
Amaranthus viridis & 0.09 \\
\hline Total & 411.88 \\
\hline
\end{tabular}

\subsection{Maize Spatial Arrangement and Weed Response}

Weed response is conditioned on maize spatial arrangement. This suggests that a lower number of weeds were found at high plant densities combined with low row spacing and vice-versa (Figure 3). Weeds developed well at 
$0.50 \mathrm{~m}$ row spacing with 6.5 plants $\mathrm{m}^{-2}$. They presented higher value compared to other treatments. At plant density of 8.0 plants $\mathrm{m}^{-2}$ in row spacing of $0.35 \mathrm{~m}$, we found better weed control than the recommended maize population $\left(0.50 \mathrm{~m} \times 5.0\right.$ plants $\left.\mathrm{m}^{-2}\right)$ and, certainly, other treatments here tested.
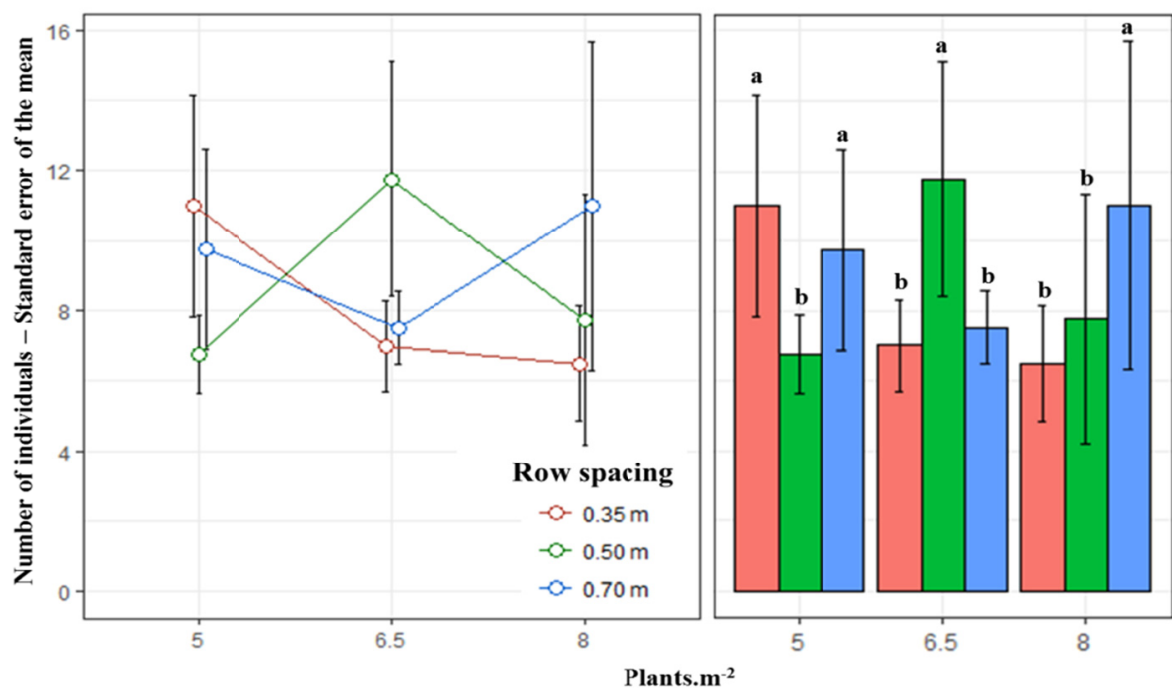

\section{Row spacing}

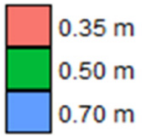

Figure 3. Estimated mean of weed population within three row spacing and plant densities

A two-way ANOVA revealed that the plant population density had significant influence over weed growth (Table 6). This result is significant according to the Tukey's test, $p \leq 0.05$ (Table 7). Row spacing by itself did influence or interfere on weed development. Moreover, the interaction between the two factors was significant at Tukey test and the coefficient of variation (CV) was around $25 \%$ showing high dispersion in the population. They represent the reality of maize in field.

Table 6. Analysis of variance of the number of weeds within the interaction of maize population density and row spacing

\begin{tabular}{llllll}
\hline & DF & SS & MS & Fc & P $>$ Fc \\
\hline Block & 3 & 2.7226 & 0.90752 & 3.5046 & 1.0994 \\
Rs & 2 & 0.1363 & 0.06813 & 0.2631 & 0.77087 \\
Pd & 2 & 0.3020 & 0.15101 & 0.5832 & 0.56585 \\
Rs $*$ Pd & 4 & 1.1387 & 0.28468 & 1.0994 & 0.37956 \\
Residuals & 24 & 6.2149 & 0.25895 & & \\
Total & 35 & 10.5145 & & & \\
\hline CV $(\%)$ & 25.17 & & & & \\
\hline
\end{tabular}

Note. $\mathrm{Rs}=$ Row spacing; $\mathrm{Pd}=$ Plant density; $\mathrm{CV}=$ Coefficient of Variation; $\mathrm{DF}=$ Degrees of Freedom; $\mathrm{SS}=$ Sum of Squares; $\mathrm{MS}=$ Mean sum of Squares; $\mathrm{Fc}=\mathrm{F}$ critical value; $\mathrm{P}=\mathrm{P}$ value.

Table 7. Average weeds within the interaction of maize population density and row spacing

\begin{tabular}{llll}
\hline & $\mathbf{5 . 0}$ plants $\mathbf{~ m}^{-\mathbf{2}}$ & $\mathbf{6 . 5}$ plants $\mathbf{~ m}^{-2}$ & $\mathbf{8 . 0}$ plants $\mathbf{~ m}^{\mathbf{2}}$ \\
\hline $\mathbf{0 . 3 5} \mathbf{~ m}$ & $8.64 \mathrm{a}$ & $5.62 \mathrm{~b}$ & $4.63 \mathrm{~b}$ \\
$\mathbf{0 . 5 0} \mathbf{~ m}$ & $5.51 \mathrm{~b}$ & $9.37 \mathrm{a}$ & $4.87 \mathrm{~b}$ \\
$\mathbf{0 . 7 0} \mathbf{~ m}$ & $7.68 \mathrm{a}$ & $6.27 \mathrm{~b}$ & $7.84 \mathrm{a}$
\end{tabular}

Note. Average followed by the same letter in the column does not differ from one another by Tukey's grouping test $(\mathrm{P}<0.05)$. 


\section{Discussion}

As described on the results section, three specimen's families had high observations. These are Amaranthaceae, Poaceae and Fabaceae. The first one represents plants, predominantly herbs, that are common in temperate and tropical regions. These plants have a branched tap root. Representing Poaceae family is grass, usually herbaceous, that presents fibrous root. Last but not least, Fabaceae is also called Leguminosae and they are distributed mostly tropical and subtropical regions. During maize development, there may be an interspecific competition between weeds and maize, and intraspecific competition among maize. The interspecific competition occurs because of the low plant density and high row spacing. Just as weeds compete for water and nutrients, the main crop (maize) has its development affected resulting in yield losses. However, farmers can use this competition in favour of maize when they sow at high plant density and reduce row spacing achieving yield gains, and performing a physical weed control. One of the causes must be related to the rapid canopy closure between the rows by maize plants, in reduced spacing and in high population, struggling the germination and growth of weeds between the rows of the maize crop. The results described here are in agreement with those obtained by Kolb, Gallandt, and Molloy (2010). They studied physical weed control versus interspecific competition in organic spring barley and found improvements with respect to weed control at wide row strategy. Moreover, the narrower row and higher plant density approach of maize can reduce transpiration and photosynthesis of weeds. Barros et al. (2017) described in their study the physiological response of maize and weeds living under different densities and their results further support the idea of reducing row spacing and increasing plant density on weed control. The results of our study are in agreement with those of previous and recent research (Chauhan \& Johnson, 2011; Johnson \& Hoverstad, 2002; Mhlanga, Chauhan, \& Thierfelder, 2016; Mohammadi, Ghobadi, \& Shaekheh-Poor, 2012). The effectiveness of maize arrangement was tested by Mendes, Drews, Medeiros, Rosa, Gualberto, and Mielezrski (2017) in the same study area. Therefore, they achieved better yield gains with narrower row spacing $(0.35 \mathrm{~m})$ combining 8.0 plants $\mathrm{m}^{-2}$. Statistically, the interaction of both parameters had more impact on weed control rather than only row spacing or the plant density factor. This is because of canopy closure. High plant densities can accelerate canopy development and consequently weed suppression resulting in low competition between weed and maize for water and nutrients, which are vital for maize growth under semiarid or any environmental conditions. Additionally, physical plant attributes can lead to a viable competition against weeds, such as early canopy closure (Bajwa, Walsk, \& Chauhan, 2017; Fahad et al., 2015; Weerarathne, Marambe, \& Chauhan, 2017). Another interesting point is, according to the results observed, we can assume that economic and environmental trends could be solved because of reducing herbicides applications. Hence, this can increase farmers' incomes and yield results contributing positively to the environment. Colbach et al. (2017) simulated different cropping practices using glyphosate-resistant maize. The authors concluded that combining weed control methods with different cropping practices can reach farmers and food production needs. Furthermore, selecting and analysing weed species abundance in the field may help to decide which combined approaches are sustainable, economic, environment, and social. Phytosociological survey not only help to identify weed specimen importance aiming to control them, but also have a crucial role identifying exotic species that were not consider weed, but can become one. Our survey, for example, allowed us to classify L. leucocephala as weed in this experiment. Even though Leucaena is a species applied in reforestation and/or feeding cattle under semiarid regions, they can be troublesome for farmers during maize development. Costa and Durigan (2010) conducted a study evaluating if L. leucocephala acts as a weed disturbing environmental equilibrium or not. They concluded that L. leucocephala was a weed. Our results support their research presenting Leucaena as an invasive species on maize crop. The Brazilian weed guide does not have this species on its catalogue and it certainly should be included in the next update.

\section{Conclusion}

Spatial arrangements with reduced spacing and high population decrease the presence of weed in maize. Moreover, the best weed control was reached with plant density of 8.0 plants $\mathrm{m}^{-2}$ in row spacing of $0.35 \mathrm{~m}$. The recommended maize population that is 5.0 plants $\mathrm{m}^{-2}$ in a row spacing of $0.50 \mathrm{~m}$ had a good weed control, however, not as efficient as the treatment using 8.0 plants $\mathrm{m}^{-2}$ at the row spacing of $0.35 \mathrm{~m}$. The statistics showed that the weed control suffers more influence from the plant density factor than the row spacing, or the interaction of both parameters. Among the specimen's families identified on the field, Fabaceae, Poaceae and Amaranthaceae deserve to be highlighted due to its high values of density, frequency and dominance. Additionally, Leucaena leucocephala was classified as a weed in the maize field.

\section{References}

Ahmad, Z., Khan, S. M., Abd Allah, E. F., Alqarawi, A. A., \& Hashem, A. (2016). Weed species composition and distribution pattern in the maize crop under the influence of edaphic factors and farming practices: A case 
study from Mardan, Pakistan. Saudi Journal of Biological Sciences, 23(6), 741-748. https://doi.org/ 10.1016/j.sjbs.2016.07.001

Alvares, C. A., Stape, J. L., Sentelhas, P. C., de Moraes Gonçalves, J. L., \& Sparovek, G. (2013). Köppen's climate classification map for Brazil. Meteorologische Zeitschrift, 22(6), 711-728. https://doi.org/10.1127/ 0941-2948/2013/0507

Bajwa, A. A., Walsh, M., \& Chauhan, B. S. (2017). Weed management using crop competition in Australia. Crop Protection, 95, 8-13. https://doi.org/10.1016/j.cropro.2016.08.021

Barros, R. E., Faria, R. M., Tuffi Santos, L. D., Azevedo, A. M., \& Governici, J. L. (2017). Physiological Response of Maize and Weeds in Coexistence. Planta Daninha, 35. https://doi.org/10.1590/s0100-8358 2017350100027

Braun-Blanquet, J. (1979). Fitosociología: Bases para el estudio de las comunidades vegetales. Fitosociología: Bases Para El Estudio de Las. Retrieved from http://bases.bireme.br/cgi-bin/wxislind.exe/iah/online $/$ ?IsisScript $=$ iah/iah. $x$ is\&src=google\&base=REPIDISCA\&lang=p\&nextAction=lnk\&exprSearch=148669\&i ndexSearch=ID

Brunharo, C. A. D. C. G., Christoffoleti, P. J., \& Nicolai, M. (2014). Aspectos do mecanismo de ação do amônio glufosinato: Culturas resistentes e resistência de plantas daninhas. Revista Brasileira de Herbicidas, 13(2), 163. https://doi.org/10.7824/rbh.v13i2.293

Chauhan, B. S., \& Johnson, D. E. (2011). Row spacing and weed control timing affect yield of aerobic rice. Field Crops Research, 121(2), 226-231. https://doi.org/10.1016/j.fcr.2010.12.008

Colbach, N., Darmency, H., Fernier, A., Granger, S., Le Corre, V., \& Messéan, A. (2017). Simulating changes in cropping practices in conventional and glyphosate-resistant maize. II. Weed impacts on crop production and biodiversity. Environmental Science and Pollution Research, 24(14), 13121-13135. https://doi.org/10.1007/ s11356-017-8796-9

CONAB. (2016). Presidente da República. Retrieved from http://www.conab.gov.br/OlalaCMS/uploads/arquivos /17_03_14_15_28_33_boletim_graos_marco_2017bx.pdf

Concenço, G., Tomazi, M., Correia, I. V., Santos, S. A., \& Galon, L. (2013). Phytosociological surveys: Tools for weed science? Planta Daninha, 31(2), 469-482. https://doi.org/10.1590/S0100-83582013000200025

Costa, J. N. M. N., \& Durigan, G. (2010). Leucaena leucocephala (Lam.) de Wit (Fabaceae): invasora ou ruderal? Revista Árvore, 34(5), 825-833. https://doi.org/10.1590/S0100-67622010000500008

Erasmo, E., Pinheiro, L., \& Costa, N. (2004). Levantamento fitossociológico das comunidades de plantas infestantes em áreas de produção de arroz irrigado cultivado sob diferentes sistemas de manejo. Planta Daninha, 22(2), 195-201. https://doi.org/10.1590/S0100-83582004000200004

Fahad, S., Hussain, S., Chauhan, B. S., Saud, S., Wu, C., Hassan, S., ... Huang, J. (2015). Weed growth and crop yield loss in wheat as influenced by row spacing and weed emergence times. Crop Protection, 71, 101-108. https://doi.org/10.1016/j.cropro.2015.02.005

Ferreira, E. B., Cavalcanti, P. P., \& Nogueira, D. A. (2014). ExpDes: An R Package for ANOVA and Experimental Designs. Applied Mathematics, 5(19), 2952-2958. https://doi.org/10.4236/am.2014.519280

Freitas, W. K., \& Magalhães, L. M. S. (2012). Métodos e Parâmetros para Estudo da Vegetação com Ênfase no Estrato Arbóreo. Floresta E Ambiente, 19(4), 520-540. https://doi.org/10.4322/floram.2012.054

Johnson, G. A., \& Hoverstad, T. R. (2002). Effect of Row Spacing and Herbicide Application Timing on Weed Control and Grain Yield in Corn (Zea mays). Weed Technology, 16(3), 548-553. https://doi.org/10.1614/ 0890-037X(2002)016[0548:EORSAH]2.0.CO;2

Kolb, L. N., Gallandt, E. R., \& Molloy, T. (2010). Improving weed management in organic spring barley: Physical weed control vs. interspecific competition. Weed Research, 50(6), 597-605. https://doi.org/ 10.1111/j.1365-3180.2010.00818.x

Lorenzi, H. (2006). Manual de identificação e controle de plantas daninhas (p. 299). Nova Odessa: Editora Plantarum Ltda.

Mendes, W. S., Drews, T. A., Medeiros, J. C., Rosa, J. D., Gualberto, A. V. S., \& Mielezrski, F. (2017). Development and productivity of maize in response to spatial arrangement under semiarid condition of Northeastern Brazil. Australian Journal of Crop Science, 11(3), 313-321. https://doi.org/10.21475/ 
ajcs.17.11.03.pne389

Mesquita, M. L. R., Andrade, L. A., \& Pereira, W. E. (2016). Germination, floristic composition and phytosociology of the weed seed bank in rice interropped with corn fields. Revista Brasileira de Ciências Agrárias, 11(1), 14-20. https://doi.org/10.5039/agraria.v11i1a5359

Mhlanga, B., Chauhan, B. S., \& Thierfelder, C. (2016). Weed management in maize using crop competition: A review. Crop Protection, 88, 28-36. https://doi.org/10.1016/j.cropro.2016.05.008

Mohammadi, G. R., Ghobadi, M. E., \& Sheikheh-Poor, S. (2012). Phosphate Biofertilizer, Row Spacing and Plant Density Effects on Corn (Zea mays L.) Yield and Weed Growth. American Journal of Plant Sciences, 3, 425-429. https://doi.org/10.4236/ajps.2012.34051

Mueller-Dombois, D., \& Ellenberg, H. (1974). Aims and Methods of Vegetation Ecology (p. 547). John Wiley \& Sons.

Pires, N. de M., Prates, H. T., Pereira Filho, I. A., Oliveira Jr., R. S. de, \& Faria, T. C. L. de. (2001). Atividade alelopática da leucena sobre espécies de plantas daninhas. Scientia Agricola, 58(1), 61-65. https://doi.org/ 10.1590/S0103-90162001000100011

R Development Core Team. (2017). R language definition. Vienna, Austria: R Foundation for Statistical Computing. Retrieved from http://web.mit.edu/ r/current/arch/amd64_linux26/lib/R/doc/manual/R-lang.pdf

Soil Survey Staff. (2014). Keys to soil taxonomy. In Natural Resources Conservation Service (Ed.), U.S. Department of Agriculture Handbook (12th ed.). Retrieved from https:/www.nrcs.usda.gov/Internet/ FSE_DOCUMENTS/nrcs142p2_051232.pdf

Weerarathne, L. V. Y., Marambe, B., \& Chauhan, B. S. (2017). Intercropping as an effective component of integrated weed management in tropical root and tuber crops: A review. Crop Protection, 95, 89-100. https://doi.org/10.1016/j.cropro.2016.08.010

\section{Copyrights}

Copyright for this article is retained by the author (s), with first publication rights granted to the journal.

This is an open-access article distributed under the terms and conditions of the Creative Commons Attribution license (http://creativecommons.org/licenses/by/4.0/). 